HYGIENE AND SOCIAL MEDICINE

УДК 613.9+614.253.4

DOI: 10.26565/2617-409X-2019-4-06

\title{
PHYSICAL ACTIVITY TRENDS IN THE WORLD AND AMONG MEDICAL STUDENTS
}

\author{
Agwu Chigborum Charles, Enescan Koseoglu, Halyna Holubhycha, Nursel Abas
}

Mail for correspondence: charleschigborum@gmail.com

Summary: Physical activity is currently one of the most important components of health and longevity. Our environment has changed significantly lately. Technological progress is growing very fast. The technology around us shows us comfort. All these factors significantly reduce the level of physical activity in everyday life. This increases the level of noncommunicable diseases, which significantly reduce the quality of life and life expectancy of people around the world. All that we need, with such a significant decline in our health is physical exercise. The aim of the study is to study the trends in the level of physical activity in the world and among medical students during training. To achieve these goals, an information-analytical analysis of the level of physical activity in the world was carried out, as well as data on the level of physical activity of students were analyzed. The article provides literature data on the quantitative and qualitative composition of physical activity in everyday life, individual data on the level of physical activity of medical students. Weekly physical activity was from $31.7 \%$ to $35.1 \%$ at different periods of study. At the same time, the absence or low level of physical activity was noted among third-year students $-62.5 \%$ and $40.5 \%(p<0.05)$ in the fifth year of study. With these positive changes in the student learning process, it was found that from $20.6 \%$ to $24.3 \%$ of students spend less than two hours a day communicating on social networks. All the rest spend much more time on this type of communication. It was found that the level of physical activity is very low. To achieve the normative level of physical activity, which has a direct relationship with health, It is necessary to increase public awareness on the importance of physical activity and its impact on health, as well as to recommend a reduction in student's time management, and to provide them with the opportunity to participate in sporting activities.

Key words: physical activity, technological progress, healthy lifestyle, students

\section{Information about author}

Agwu Chigborum Charles,

V. N. Karazin Kharkiv National University,

Kharkiv School of Medicine, 4th year

student, 6, Svobody Sq., 61022, Kharkiv,

Ukraine

charleschigborum@gmail.com

Enescan Koseoglu V. N. Karazin

Kharkiv National University, Kharkiv

School of Medicine, 3rd year student, 6,

Svobody Sq., 61022, Kharkiv, Ukraine
Halyna Holubhycha, MD, Assistant of department of Hygiene and Social Medicine, V. N. Karazin Kharkiv National University, Svobody sq. 4, Kharkiv, Ukraine, 61022; Junior scientific worker of the Department of the Scientific Organization of Medical Assistance to Schoolchildren and Adolescents of the State Enterprise "Institute for the Protection of Children and Adolescent Health of the National Academy of Medical Sciences of Ukraine" Yuvileinyi Avenue 52a, Kharkiv, Ukraine, 61153, galj6566@ gmail.com, https://orcid.org/0000-0001-7832-20591

Nursel Abas, Student V. N. Karazin Kharkiv National University, Kharkiv School of Medicine, 3rd year student, 6, Svobody Sq., 61022, Kharkiv, Ukraine

\section{Introduction}

Physical activity is defined as any movement of the body produced by skeletal muscles, which requires energy. Inadequate physical activity is responsible for over $6 \%$ of deaths in the world. In addition, according to $\mathrm{WHO}$, most cases of breast and colon diseases account for $21-25 \%$ of cases, $27 \%$ of cases of diabetes and about $30 \%$ of cases of coronary heart disease [1]. A regular and adequate level of physical activity in adults: reducing the risk of hypertension, coronary heart disease, stroke, diabetes, breast and colon cancer, depression and the risk of falls; improve bone and functional health; and therefore, fundamental to energy balance and weight control. The term "physical activity" is not "physical exercise". Exercise is a subcategory of physical activity that is planned, structured, repetitive, and focused in the sense that it is the goal of improving or supporting one or more components of physical fitness. Physical activity includes physical exercises, as well as other activities that are associated with body movement and are performed as part of the game, work, active walks, housework and recreation.

Over the past two centuries, the level of physical activity has significantly decreased, while daily mankind finds new opportunities to deal with serious, previously fatal diseases. At the same time, a sedentary lifestyle, to one degree or another, is the cause of many of them.

Increasing physical activity is a social, not an individual, problem. Therefore, it requires a 
population-based, multisectoral, interdisciplinary and culturally significant approach [2].

who are inactive? Moderate to active regular physical activity also reduces feelings of anxiety and depression and improves sleep and quality of life. Even one episode of physical activity provides a temporary improvement in cognitive function and anxiety. Adults who are more physically active are better able to perform everyday tasks without excessive fatigue. A moderate to active increase in physical activity is associated with improved cardiorespiratory and muscular performance, including healthier body mass and body composition. Adults who are more physically active can more easily perform daily tasks, such as climbing stairs, carrying heavy packages, and doing household chores. These benefits apply to men and women of all ages, races, and ethnic groups. Adults get most of this health benefit when they do the equivalent of 150 to 300 minutes ( 2 hours and 30 minutes to 5 hours) of moderate-intensity aerobic activity every week. Adults receive additional and more significant health benefits with even greater physical activity. Muscle strengthening measures are also good for health and are an important part of the overall plan of physical activity of an adult. Adults should move more and sit less during the day. Some physical activity is better than nothing. Adults who sit less and engage in any moderate to active physical activity receive some health benefits [3-5].

The life quality of individual elderly Ukrainian citizen is low. The higher life quality can be associated with higher physical activity level. The intense exercise was not an obligatory condition for optimal health and good life quality of elderly people. Significant correlation between life quality scales and the high-intensity physical work was identified only for scale Physical Functioning. Instead active part in daily activities - walking, lifting the stairs, farm work, and housework can improve significantly life quality of elderly people [6].

The comparison of students' PA from selected European countries, members of the Visegrad group and Ukraine, is particularly vital to the latter country as it demonstrates a different level of socioeconomic development. There was noted a significantly higher level of physical activity in students from the Visegrad countries than in Ukraine. Further, there was an overall lower level of physical activity in females compared to males.
What was positive about the studied samples was a healthy BMI index in the majority of the male and female respondents, with a significantly higher indicator in Ukraine [7]

\section{Materials and methods}

The aim of the study is to determine the level of physical activity in the world and among medical students during training.

To achieve this goal, an informational analysis of the level of physical activity in the world was carried out, as well as data on the level of physical activity of students were analyzed. An anonymous Adults who are physically active, healthier, feel better, and less likely to develop many chronic diseases, such as cardiovascular disease, type 2 diabetes, and several types of cancer, than adults survey of foreign medical students studying in the first, third and fifth years was conducted.

\section{Results and Discussion}

It is very important to monitor the level of physical activity of the young generation aged 18 to 25 years. The health and well-being of any nation greatly depends on their health. Young people experience significant changes in their lives, which are not always accompanied by the preservation of health. They switch to higher education or vocational education, start work and begin a career, a change in living conditions.

According to a survey of 324 foreign medical students of the first, third and fifth courses of Karazin University. The average age of which was $21.43 \pm$ 2.6 years. The following results were obtained.

$92.27 \%$ of respondents have walks in the fresh air for 2 to 4 hours; no significant difference between the courses of study was found. At the same time, data on the students' body mass index were obtained, and it showed that the number of students with normal weight when entering university is only $20 \%$. A significant increase in this indicator was noted both in the third and fifth years of study, $56.00 \%$ and $74.5 \%$, respectively $(\mathrm{p}<0.05)$. These changes are observed due to a decrease in students with insufficient body weight from $15 \%$ to $5 ; 0 \%$ ( $p<0.01$ ), and with overweight from $65 \%$ to $20.10 \%$ $(\mathrm{p}<0.05)$ (Fig. 1).

$8.6 \%$ of students in their first year of study, $6.25 \%$ in their third and $24.3 \%$ in their fifth year of study ( $p<0.05$ ) had daily physical activity. 


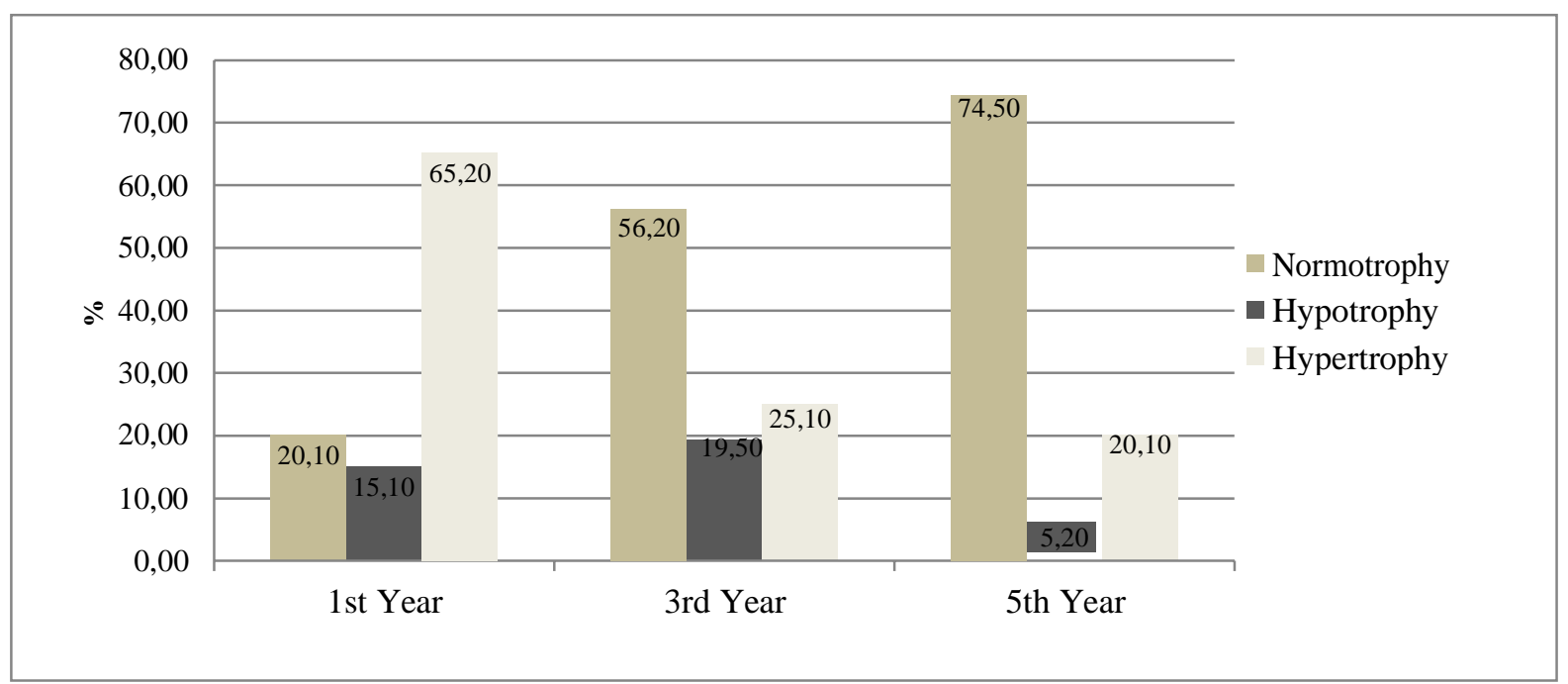

Note: \# - $\mathrm{p}<0.01$; $*$ - $<<0.05$; when compared with similar indicators of the other group.

Fig.1. Distribution of the Students according To Their Nutritional status (BMI Results)

Table 1. Daily use of social networks by foreign medical students

\begin{tabular}{|c|c|c|c|}
\hline & less than 2 hours & from 2 to 4 hours & more than 4 hours \\
\hline 1st course & $20,6 \%$ & $51,7 \%$ & $27,7 \%$ \\
\hline 3rd course & $37,5 \%$ & $31,25 \%$ & $31,25 \%$ \\
\hline 5th course & $24,3 \%$ & $45,9 \%$ & $29,8 \%$ \\
\hline
\end{tabular}

Weekly physical activity was from $31.7 \%$ to $35.1 \%$ at different periods of study. At the same time, the absence or low level of physical activity was noted among third-year students $62.5 \%$ and $40.5 \%(\mathrm{p}<0.05)$ in the fifth year of study, third-year students had an average of $56.8 \%$.

With these positive changes in the student learning process, it was found that from $20.6 \%$ to $24.3 \%$ of students spend less than two hours a day communicating on social networks. All the rest spend much more time on this type of communication (Table 1).

\section{Conclusion}

The study revealed that the nutritional routine in general, the results clearly show that physical activity affects health more than we expect. One of the most important factors in the prevention of diseases and improving living standards is the normalization of the level of physical activity.

In our study, in the first and third year of study, large similarities were revealed. The results of the fifth year look better.

In the whole year of study, we observed a significant decrease in students' physical activity and an increase in the time spent on social networks, which is one of the significant components of a sedentary lifestyle.

\section{References}

1. Global Action Plan On Physical Activity 2018-2030 (2018) Retrieved from URL: https://apps.who.int/iris/bitstream/handle/10665/272722/97892 41514187-eng.pdf

2. Global Strategy on Diet, Physical Activity and Health (2019) Retrieved from URL: https://www.who.int/dietphysicalactivity/pa/en/

3. Alex M. Azar II Secretary U.S. (2018) Physical Activity Guidelines for Americans 2nd edition Department of Health and Human Services Retrieved from URL: https:/health.gov/paguidelines/secondedition/pdf/Physical_Activity_Guidelines_2nd_edition.pdf 4. Health Communication and Health Information Technology (2018) Retrieved from URL https://www.healthline.com/nutrition/10-benefits-of-exercise 5. Lawrence Robinson, Jeanne Segal, Ph.D., and Melinda Smith, M.A. Last updated. (2019) The Mental Health Benefits of Exercise Retrieved from URL:

https://www.helpguide.org/articles/healthy-living/the-mentalhealth-benefits-of-exercise.htm?pdf=13390 June 2019

6. Iuliia Pavlova, Bogdan Vynogradskyi, Zbigniew Borek, Irena Borek (2015) Life quality and physical activity of Ukrainian residents https: Journal of Physical Education and Sport Vol., 15(4), Art 124, pp. 809 - 814. Retrieved from URL: efsupit.ro/images/stories/nr4.2015/Art124.pdf 


\title{
ТЕНДЕНЦЇ̈ ФІЗИЧНОЇ АКТИВНОСТІ У СВІТІ ТА СЕРЕД СТУДЕНТІВ-МЕДИКІВ
}

\author{
Аггу Чигборум Чарльз, Енескан Косеоглу, Голубчича Г. І., Нурсель Абас
}

Пошта для листування: charleschigborum@gmail.com

\begin{abstract}
Резюме: Фізичні навантаюення в даний час є однією з найваюливіших складових здоров'я та довголіття. Наше середовище останнім часом суттєво змінилося. Технологічний прогрес зростає дужсе швидко. Технологія навколо нас показує нам комфорт. Всі изі фактори суттєво знижують рівень фізичної активності в повсякденному жстті. Це підвишує рівень неінфекиійних захворювань, щзо суттєво знижує якість життя та тривалість жсття людей у всьому світі. Все, щуо нам потрібно, при такому значному зниженні нашого здоров'я, це фізичні вправи. Метою дослідження $\epsilon$ вивчення тендениій рівня фізичної активності у світі та серед студентів-медиків під час навчання. Для досягнення цих иілей було проведено інформачійно-аналітичний аналіз рівня фізичної активності у світі, а також проаналізовано дані про рівень фізичної активності учнів. У статті наведено літературні дані про кількісний та якісний склад фізичних навантажень у повсякденному житті, індивідуальні дані про рівень фізичної активності студентів-медиків. Тиюсневі фізичні навантажсення в різні періоди дослідження становили від 31,7\% до 35,1\%. У той же час спостерігався низький рівень фізичної активності, особливо серед студентівтретього курсу - 62,5\% та 40,5\% 3 урахуванням циих позитивних змін у прочесі навчання студентів було встановлено, щуо від 20,6\% до 24,3\% студентів проводять мение двох годин на день, спілкуючись у сочіальних мережсах. Всі іниі витрачають набагато більше часу на ичей тип спілкування. Було встановлено, щзо рівень фізичної активності дужсе низький. Для досягнення нормативного рівня фізичної активності, щзо має прямий зв'язок із здоров'ям, необхідно підвищчтти поінформованість громадськості щчодо ваюливості фізичної активності та їі впливу на здоров'я, а також рекомендувати скорочення часом на використання сочуільних мережсстудентомитазабезпечити їмможливість брати участь урізнихзаходах.
\end{abstract}

Ключові слова: фізичні навантаження, технологічний прогрес, здоровий спосіб життя, студенти

Інформація про авторів

Агву Чігборум Чарльз, студент 4-го

курсу медичного факультету

Харківського національного

університету імені В. Н. Каразіна, 61022,

майдан Свободи, 6, Харків, 61022

charleschigborum@gmail.com

Енескан Косеоглу, студент 3-го курсу медичного факультету Харківського національного університету імені В. Н. Каразіна, майдан Свободи, 6, Харків, 61022 enescankoseoglu@gmail.com

Голубнича Галина Ігорівна, асистент кафедри гігієни та соціальної медицини Харківського національного університету імені В. Н. Каразіна, майдан Свободи, 6, Харків, 61022молодший науковий співробітник відділення наукової організації медичної допомоги школярам i підліткам ДУ «Інститут охорони здоров'я дітей та підлітків Національної академії медичних наук України» 61153 , Харків, пр. Ювілейний, 52a, galj6566@gmail.com

https://orcid.org/0000-0001-7832-20591

Нурсель Абас, студентка 3-го курсу медичного факультету Харківського національного університету імені В. Н. Каразіна, майдан Свободи, 6, Харків, 61022

abasnursel@gmail.com

\section{ТЕНДЕНЦИИ ФИЗИЧЕСКОЙ АКТИВНОСТИ В МИРЕ И СРЕДИ СТУДЕНТОВ- МЕДИКОВ}

\author{
Аггу Чигборум Чарльз, Енескан Косеоглу,. Голубчичая Г.И., Нурсель Аббас
}

Пошта для листування: charleschigborum@gmail.com

Резюме. Физические нагрузки в настоящуее время является одной из важнейших составляюших здоровья и долголетия. Нашу среду в последнее время сущчественно изменилось. Технологический прогресс растет очень быстро. Технология вокруг нас показывает нам комфорт. Все эти факторы существенно снижают уровень физической активности в повседневной жизни. Это повышает уровень неинфекционных заболеваний, существенно снижает качество жизни и продолжительность жизни людей во всем мире. Все, что нам нужно, при таком значительном снижении нашего здоровья, это физические упражнения.Целью исследования является изучение тенденций уровня физической активности в мире и среди студентов-медиков во время учебы. Для достижения этих целей были проведены информационно-аналитический анализ уровня физической активности в мире, а также проанализированы данные об уровне физической активности учашчихся. B статье приведень литературные данные о количественном и качественном составе физических нагрузок в повседневной жизни, индивидуальные данные об уровне физической активности студентов-медиков. Недельньее физические нагрузки в разные периоды исследования составили от 31,7\% до 35,1\%. В то же время наблюдался низкий уровень физической активности, особенно среди студентов третьего курса - 62,5\% и 40,5\% (p <0,05) пятого курса обучения. С учетом этих позитивных изменений в процессе обучения 
